\title{
Epidemiological studies of Mansonella ozzardi (Nematoda, Onchocercidae) in indigenous communities of Pauini municipality, Amazonas, Brazil ${ }^{1}$
}

\author{
Jansen Fernandes MEDEIROS ${ }^{1}$, Victor PY-DANIEL, Ulysses Carvalho BARBOSA, \\ Emanuelle de Souza FARIAS
}

\section{ABSTRACT}

The Mansonella ozzardi has a widespread distribution among the indigenous and riverine communities of Amazonas, Brazil. We estimated the prevalence of Mansonella ozzardi in indigenous communities of the Pauini municipality, Amazonas state, Brazil and the rate of parasitic infection in vectors. We collected thick blood smears from individuals from six Apurinã indigenous communities along the Purus River and its tributaries. Collections of simuliids were made and dissected, and the larval instars of M. ozzardi identified. The overall prevalence of $M$. ozzardi was $28.40 \%$, with the highest incidence among males and agricultural workers. Among age groups, children 2-9 years of age had the lowest incidence, while individuals older than 58 exhibited the highest rates of infection. We found infected simuliids in three communities, with Parasitic Infection Rates (PIR) of $0.34-6.58 \%$. The prevalence of $M$. ozzardi among the Apurina people is high, possibly related to the diary activities of the riparian people, where a high abundance of the vectors exists.

\section{KEY WORDS}

Mansonella ozzardi, Mansonelliasis, Simuliidae, Amazonas, Brazil.

\section{Estudos Epidemiológicos da Mansonella ozzardi (Nematoda, Onchocercidae) em Comunidades Indígenas do Município de Pauini, Amazonas, Brasil}

\begin{abstract}
RESUMO
Esse trabalho tem como objetivos estimar a prevalência de Mansonella ozzardi em comunidades indígenas do municipio de Pauini, Amazonas, Brasil e estimar a Taxa de Infecção Parasitária nos vetores. Foram examinados indígenas da etnia Apurinã, pelo método de gota espessa, em seis comunidades localizadas as margens e afluentes do rio Purus. A prevalência geral para M. ozzardi foi de 28,40\%, com maior incidência para o sexo masculino e nos individuos com atividade no campo (agricultores). Em relação à faixa etária, as menores prevalências foram obtidas nos individuos mais jovens (2-9 anos), enquanto as maiores nos individuos acima de 58 anos. Foram encontrados simulideos parasitados em três comunidades, com uma Taxa de Infecção Parasitária que variou de 0,34 a 6,58\%. A prevalência de M. ozzardi entre os Apuriná é elevada, possivelmente relacionada às suas atividades diárias as margens dos rios, onde existe uma grande abundância dos vetores.
\end{abstract}

\section{PALAVRAS-CHAVE}

Mansonella ozzardi, Mansonelose, Simuliidae, Amazonas, Brasil.

\footnotetext{
${ }^{1}$ Laboratório de EtnoEpidemiologia, Instituto Nacional de Pesquisas da Amazônia, CP 478, 69011-970, Manaus, Amazonas, Brasil. jmedeiro@inpa.gov.br, pydaniel@inpa.gov.br
} 
EPIDEMIOLOGICAL STUDIES OF Mansonella ozzardi (NEMATODA, ONCHOCERCIDAE) IN INDIGENOUS COMMUNITIES OF PAUINI MUNICIPALITY, AMAZONAS, BRAZIL

\section{INTRODUCTION}

Mansonella ozzardi is a filarial worm with an exclusively American distribution, and in Brazil, is found in the states of Amazonas, Mato Grosso (high River Xingu), and Roraima (Deane et al., 1954; Oliveira, 1963; D'Andretta et al., 1969). In Amazonas, this filaria has an ample distribution and infects riverine and indigenous communities of the Solimóes, Purus, and Negro Rivers and their tributaries (Lacerda \& Rachou, 1956; Moraes et al., 1978; Lawrence et al., 1980, Tavares, 1981).

Mansonelliasis is a relatively little-studied filarial disease, with doubtful pathology. The people with mansonellaisis and high microfilaremia present moderate fever, joint pains, adenitis, headaches, and coldness of the legs (Batista et al., 1960). A new symptom is the presence of visual lesions, which may lead to blindness (Branco et al., 1998; Garrido \& Campos, 2000).

The $M$. ozzardi is transmitted by dipterians insects of the families Ceratopogonidae and Simuliidae. In Brazil, only simuliids are recognized as vectors, and were first recorded by Cerqueira (1959) who found Simulium amazonicum (= Cerqueirellum argentiscutum) infected with larvae of $M$. ozzardi. Shelley \& Shelley (1976) found S. amazonicum (= C. amazonicum) incrimined as a vector in the Purus river, Amazonas; and Shelley et al. (1980) found S. amazonicum (=C. amazonicum) and $S$. argentiscutum $(=C$. argentiscutum) to be vectors in the high Solimões river. Moraes et al. (1985) demonstrated that $S$. oyapockense (= C. oyapockense) was a vector in the state of Roraima.

In the Pauini region of Amazonas, a possible link between corneal lesions and mansonelliasis was discovered while Branco et al. (1998) were working in riverside communities. Our study is the first epidemiological work on mansonelliasis in the Pauini municipality. The objectives of this paper were to estimate human prevalence of mansonelliasis, to incriminate the simuliid species involved in transmission of $M$. ozzardi, and estimate the Rate of Parasitic Infection in the vectors.

\section{MATERIAL AND METHODS}

\section{STUDY AREA}

We studied people from indigenous communities in the municipality of Pauini ( $\left.07^{\circ} 42^{\prime} \mathrm{S} / 67^{\circ} 01^{\prime} \mathrm{W}\right)$, Amazonas state, Brazil. Pauini is located along the Purus River, in the southeast of Amazonas and is accessible only by water or air. We visited the communities along the Purus and Pauini rivers by boat.

\section{ESTIMATES OF HUMAN PREVALENCE}

We examined individuals from six indigenous communities Apurinã (Caciriqui, Mapiri, Makiri, Peneri, Afogados and Jagunço) considering sex, age and occupation (farmer, housewives, students, children, and adults without formal occupations), in November 2004 and May 2005. The sample was done in individuals of both sexs ( $\geq 2$ years of age) and at least $50 \%$ or more of the populations of all visited communities were examined. We estimated $M$. ozzardi prevalence using thick blood smears obtained by digital punctures. We collected two drops of blood from each individual and placed them on a glass slide, covering approximately a $1.5 \times 1.5 \mathrm{~cm}$ area (about 0.02 $\mathrm{ml})$. After air-drying, the blood was dehemoglobinized in methalene blue, stained with Giemsa solution, and then washed with distilled water. We examined the slides under light microscopes, using the $10 \mathrm{x}$ and $20 \mathrm{x}$ objectives, and when positive slides were found, the microfilariae were identified following Orihel et al. (1997). We then counted the number of microfilariae per smear. We obtained permission from each participating individual adult, or in the case of children, their parents.

\section{SIMULIID CAPTURE AND DISSECTION}

Simuliids black flies were caught in several communities using a rapid entomological assessment technique using manual suction collectors. Simuliids were placed in test tubes containing $70 \%$ ethanol and identified as to species in our laboratory.

The black flies were stained with acid hematoxilin during a period of 48 hours and dissected using a stereomicroscope. We divided each collected simuliid into three parts (head, thorax, and abdomen) using a stylet. We placed the three parts on a slide, each in their own drop of glycerin and covered with a cover slip, and the slides were examined under a light microscope. When filarial worms were found, we identified and classified then as to developmental stage (Mf, L1, L2, or L3), and then quantified them following Yarzábal et al. (1985).

We calculated the Parasitic Infection Rate (PIR) as the number of black flies parasited by $M$. ozzardi of any stage divided by the total number of females collected, multiplied by 100 .

\section{DATA ANALYSIS}

We estimated human prevalence among different sex, age, and occupation classes. Male and female prevalence was compared using the non-parametric "G-test". We used "Spearman rank-correlation" considering the prevalence and age groups and among the number of microfilaria parasitizing individuals in different age groups.

\section{RESULTS}

We examined a total of 169 individuals ( 90 men and 79 women) between the ages of 2 and 71 and found 48 individuals parasitized (28.40\%), with significantly higher prevalence in men (28 individuals, $31.33 \%$ ) than women (20 individuals, $25.32 \%)(\mathrm{G}=34.44$, d.f. $5, \mathrm{P}<0.001)$. The community of Makiri had the lowest infection rates (18.57\%), while Afogados had the highest $(43.48 \%)$. The mean number of microfilariae found in blood smears varied among communities, with the 
highest numbers in the communities of Afogados $(83.40 \pm 166.93)$ and Caciriqui $(61.66 \pm 106.80)$ (Table 1).

Among age groups, we found the lowest infection rates in individuals in their first decades of life (2-9 years, $8.33 \%$ individuals infected; $10-18$ years, $11.63 \%$ individuals infected). Prevalence was highest among individuals older than 58 $(80.00 \%)$. These trends were the same in both men and women and we found a positive correlation between age and prevalence $\left(\mathrm{r}_{\mathrm{m}}=0.78, \mathrm{r}_{\mathrm{f}}=0.82 \mathrm{P}<0.05\right)($ Table 2, Figure 1$)$.

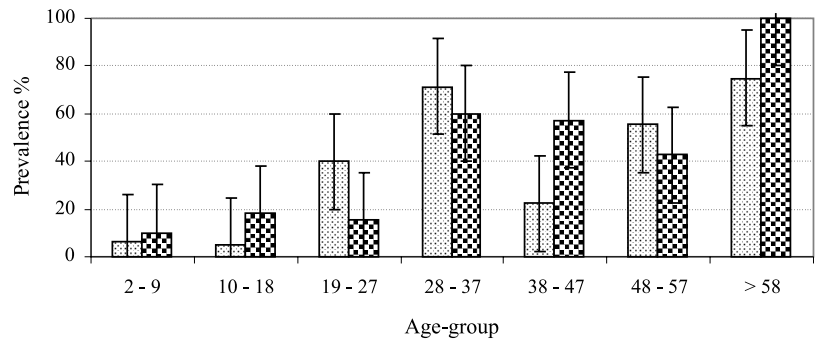

․․ Memale

Figure 1 - Prevalence of Mansonella ozzardi by age in indigenous communities in November/2004 and May/2005, Pauini municipality, Amazon state, Brazil.

Table 1 - Number of individuals examined/positive for Mansonella ozzardi by sex in indigenous communities in November/2004 and May/2005, Pauini municipality, Amazon state, Brazil.

\begin{tabular}{cccccccc}
\hline & \multicolumn{3}{c}{ Positive/ Examined } & \multicolumn{3}{c}{ Prevalence \% } & \multirow{2}{*}{$\begin{array}{c}\text { Mean of } \\
\text { mf./individual }\end{array}$} \\
\cline { 2 - 7 } Communities & Males & Females & Total & Males & Females & Total & \\
\hline Caciriqui & $5 / 10$ & $1 / 9$ & $6 / 19$ & 50.00 & 11.11 & 31.58 & $61.66 \pm 106.80$ \\
Mapiri & $3 / 12$ & $2 / 7$ & $5 / 19$ & 25.00 & 28.57 & 26.31 & $28.40 \pm 30.90$ \\
\hline Makiri & $4 / 12$ & $2 / 20$ & $6 / 32$ & 33.33 & 10.00 & 18.57 & $48.33 \pm 69.78$ \\
\hline Peneri & $9 / 42$ & $10 / 28$ & $19 / 70$ & 21.43 & 32.14 & 27.14 & $30.26 \pm 50.06$ \\
\hline Afogados & $6 / 11$ & $4 / 12$ & $10 / 23$ & 54.54 & 33.33 & 43.48 & $83.40 \pm 166.93$ \\
Jagunço & $1 / 3$ & $1 / 3$ & $2 / 6$ & 33.33 & 33.33 & 33.33 & $12.00 \pm 5.06$ \\
\hline Total & $28 / 90$ & $20 / 79$ & $48 / 169$ & 31.11 & 25.32 & 28.40 & $46.56 \pm 92.85$ \\
\hline mf. = microfilariae & & & & & & \\
\hline
\end{tabular}

The mean number of parasites in blood samples was greater in males $(68.50 \pm 116.12)$ than females $(15.85 \pm 21.51)$. Overall, individuals in age groups 2-9 and 8-10 years had the lowest mean number of microfilariae per sample. In males, we found the highest microfilaria numbers in individuals aged 48-57 $(74.20 \pm 62.80)$ and above $58(151.83 \pm 201.7)$. We found a significant correlation between mean number of microfilariae and age $(r=0.52, P<0.05)$. In females, we found the highest number of microfilariae per blood smear in women aged 28-37 $(36.00 \pm 52.94)$ (Table 2). A 60-year old man from the community of Afogados had the highest number of microfilariae per slide in the study with 549 microfilariae in two drops of blood.

Among occupation categories, individuals who work outdoors (farmers) had the highest prevalence (47.73\%), as well as mean microfilaremia $(78.89 \pm 131.87)$. Housewives had the next highest prevalence $(35.48 \%)$, and a mean number of parasites of $21.00 \pm 27.81$ (Table 3).

In order to know the Parasitic Infection Rate (PIR) of mansonelliasis vectors, we collected specimens of the simuliid species $C$. amazonicum biting humans in three communities. In Caciriqui, of the 171 simuliids collected, three were infected with a PIR of $1.75 \%$. The community of Mapiri had the highest PIR, 6.38\%, six of the 94 simulids collected. We collected 185

Table 3 - Prevalence of Mansonella ozzardi in relation to occupation of individuals in indigenous communities in November/2004 and May/2005, Pauini municipality, Amazon state, Brazil.

\begin{tabular}{cccc}
\hline Occupation & Positive/ Examined & Prevalence (\%) & $\begin{array}{c}\text { Mean of } \\
\text { mf./occupation }\end{array}$ \\
\hline Farmer & $18 / 38$ & 47.37 & $78.89 \pm 131.87$ \\
\hline Housewife & $11 / 31$ & 35.48 & $21.00 \pm 27.81$ \\
Student & $4 / 39$ & 10.26 & $10.00 \pm 8.70$ \\
$\begin{array}{c}\text { Without a formal } \\
\text { occupation } \\
\text { Other* }\end{array}$ & $2 / 20$ & 10.00 & $1.50 \pm 0.70$ \\
\hline *blind person, teacher. & $2 / 2$ & 100.00 & $13.5 \pm 10.60$ \\
\hline
\end{tabular}

Table 2 - Prevalence of Mansonella ozzardi by age and sex in indigenous communities in November/2004 and May/2005, Pauini municipality, Amazon state, Brazil.

\begin{tabular}{|c|c|c|c|c|c|c|c|c|}
\hline \multirow[b]{2}{*}{ Age group } & \multicolumn{3}{|c|}{ Examined } & \multicolumn{3}{|c|}{ Infected (Prevalence \%) } & \multicolumn{2}{|c|}{ Mean of mf./sex } \\
\hline & Males & Females & Total & Males & Females & Total & Males & Females \\
\hline $2-9$ & 16 & 20 & 36 & $1(6.25)$ & $2(10.00)$ & $3(8.33)$ & 2.0 & $11.00 \pm 14.14$ \\
\hline $10-18$ & 21 & 22 & 43 & $1(4.76)$ & $4(18.18)$ & $5(11.63)$ & 7.00 & $7.00 \pm 4.89$ \\
\hline $19-27$ & 20 & 13 & 33 & $8(40.00)$ & $2(15.38)$ & $10(30.30)$ & $43.75 \pm 95.76$ & $12.00 \pm 5.65$ \\
\hline $28-37$ & 7 & 8 & 15 & $5(71.42)$ & $3(60.00)$ & $8(53.33)$ & $47.80 \pm 68.09$ & $36.00 \pm 52.94$ \\
\hline $38-47$ & 9 & 7 & 16 & 2(22.22) & $4(57.14)$ & $6(37.50)$ & $19.00 \pm 2.82$ & $13.75 \pm 13.67$ \\
\hline $48-57$ & 9 & 7 & 16 & $5(55.55)$ & $3(42.86)$ & $8(50.00)$ & $74.20 \pm 62.80$ & $19.00 \pm 16.82$ \\
\hline$\geq 58$ & 8 & 2 & 10 & $6(75.00)$ & $2(100.00)$ & $8(80.00)$ & $151.83 \pm 201.7$ & $11.50 \pm 7.77$ \\
\hline Total & 90 & 79 & 169 & $28(31.11)$ & $20(25.32)$ & $48(28.40)$ & $68.50 \pm 116.12$ & $15.85 \pm 21.51$ \\
\hline
\end{tabular}


simuliids in Peneri and found only one infected, for a PIR of $0.54 \%$. All parasites found were L1 or L2 larval stages in the thorax of the simuliids (Table 4).

Table 4 - Number of Cerqueirellum amazonicum collected and infected; Parasitic Infection Rate (PIR); larval stages of Mansonella ozzardi, during November/2004 and May/2005 in indigenous Pauini municipality, Amazon state, Brazil.

\begin{tabular}{ccccc}
\hline Communities & $\begin{array}{c}\text { Total number of } \\
\text { simuliids collected }\end{array}$ & $\begin{array}{c}\text { Simuliids } \\
\text { Infected }\end{array}$ & PIR\% & Larval stages \\
\hline Caciriqui & 171 & 03 & 1.75 & 2L1, 2L2 \\
Mapiri & 94 & 06 & 6.38 & $8 \mathrm{~L} 1,8 \mathrm{~L} 2$ \\
Peneri & 185 & 01 & 0.54 & $1 \mathrm{~L} 1$ \\
\hline
\end{tabular}

PIR = Parasitic Infection Rate

\section{DISCUSSION}

The overall mansonelliasis prevalence shows that $M$. ozzardi is widespread across Apurinã populations of the Pauini municipality. All communities had an elevated rate of mansonelliasis, ranging from $18.57 \%$ to $43.48 \%$. Moraes et al. (1978) found high prevalence among the Ticunas people, with an average infection rate of $45.7 \%$ (although in some communities he found more than $50.0 \%$ of the people examined infected) and a mean microfilaremia count per person of 37.1. In indigenous people of the Baniwa, Yanomami, Kanamari, Jaminawa, Marubo, Kashinawa, and Katukina tribes were found to have a mean prevalence of $12.0 \%$ with the highest prevalences in a Baniwa (63.0\%) and a Tikuna (35.0\%) community (Lawrence et al., 1979). They estimated mean microfilarial count per individual at 22.0, varying between 11 and 82 (Lawrence $e t$ al., 1979). In surveys in Venezuela, a mean prevalence of $16.1 \%$ in indigenous communities of the middle Orinoco and the Parima mountains was found; and a prevalence of $58.0 \%$ among indigenous people of the Caura River basin, in southwest Bolivar state was recorded (Godoy et al., 1980; Botto et al., 1983). In the Pakaraima mountains, Guyana, a prevalence of $M$. ozzardi of $10.7 \%$ in indigenous communities was observed (Nathan et al., 1982).

Moraes et al. (1978) found a non-significant difference in male-female infection rates, with slightly higher prevalence in males, and concluded that the risk of infection was the same for both sexes. In this work, we found a significantly higher prevalence in males, especially in farmers, which we believe is directly related to the degree of exposure to vectors of M. ozzardi. Due to diary activities, the men spent more time in the fields or along river margins than women; these areas have high densities of simuliids exhibiting hematophagic activity.

M. ozzardi infection can occur in the first decade of life, although we encountered low prevalence among this age group (1.77\%). Infection becomes more common in adults in the third decade of life with the highest prevalence in older individuals. Possibly due to the cumulative characteristic of this disease and because the elder people had been more exposed to the vectors, can explain these high prevalence. Other studies have also found that the probability of microfilaremia increases with age (Moraes et al., 1978; Lawrence et al., 1979; Nathan et al., 1982). In one study, approximately $90 \%$ of men over 60 were infected. Women in their third decade of life had infection rates of $60 \%$ and maintained this rate until they were 60 years old (Moraes et al., 1978).

In the Pauini region, we collected $C$. amazonicum biting humans, and some of then were infected with $M$. ozzardi. Although we captured fewer simuliids than we expected, we found high Parasitic Infection Rates (PIR) in the specimens collected. For example, in the community of Mapiri, we found a PIR of 6,38\%, while Shelley \& Shelley (1976) recorded a PIR of $0.99 \%$ in black flies captured along the Purus River, in the municipality of Lábrea. Shelley et al. (1980) found an infection rate of $3.1 \%$ in simuliids collected among the Ticunas along higher Solimones river. The diference of PIR between the studied communities just can be explained with a systematic collections of black flies during at least a year because the fluctuation of seasonality (e.g. Medeiros \& Py-Daniel, 2004). Also the population habits may influence the PIR.

We observed $M$. ozzardi directly affecting the health of the indigenous populations of Pauini. We observed that persons with mansonelliasis may have fever, headaches, and general pains in parts of the body, those symptoms may confuse with malaria (Medeiros et al., 2006). Since some government agencies still classify mansonelliasis as apathogenic, there exists no program to treat and control the transmission of this disease in affected communities.

\section{ACKNOWLDEGMENTS}

Fundação de Amparo à Pesquisas do Estado do Amazonas (FAPEAM) for funding this project and the government of the Pauini municipality. Lauro P. Camuça from Fundação Nacional de Saúde gave logistical support. We are indebted to Raimundo M. Acaraúba, Manoel P. Silva and Raimundo S. Oliveira who were fundamental to the development of this project.

\section{LITERATURE CITED}

Batista, D.; Oliveira, W.R.; Rabello, V.D. 1960. Estudo da patogenicidade da Mansonella ozzardi e da sintomatologia da mansonelose. Revista do Instituto de Medicina Tropical de São Paulo, 2(5): 281-289.

Botto, C.; Yarzábal, A.; Lugo, E.; Arango, M.; Yarzábal, L. 1983. Aspectos epidemiológicos de la mansonelosis em el Território Federal Amazonas (Venezuela). In: Filariasis humanas en el Territorio Federal Amazonas, Venezuela. Publication Cientifica, 2: $21-40$ 
Branco, B.C.; Chamon, W.; Belfort Neto, R.; Belfort Jr.; Costa, A.J.A. 1998. Achados oculares entre habitantes do município de Pauini e possível associação entre lesóes corneanas e mansonelose na Amazônia. Arquivo Brasileiro de Oftalmologia, 61(6): 674682.

Cerqueira, N.L. 1959. Sobre a transmissão da Mansonella ozzardi. Jornal Brasileiro de Medicina, 1(7): 885-914.

D’Andretta Jr.; Pio da Silva, C.M.; Kameyana, F. 1969. Ocorrência da mansonelose entre índios do alto Xingu. Revista da Sociedade Brasileira de Medicina Tropical, 3: 11.

Deane, L.; Rachou, R.G.; Lacerda, N.B.; Martins, J.B. 1954. Alguns dados relativos à prevalência de Mansonella ozzardi no Brasil. Revista Brasileira de Malariologia e Doenças Tropicais, 6: 219-224.

Garrido, C.; Campos, M. 2000. First report of presumed parasititic keratitis in indians from the Brazilian Amazon. Cornea, 19: $817-$ 819.

Godoy, G.A.; Volcan, G.; Medrano, C.; Texeira, A.; Matheus, L. 1980. Mansonella ozzardi infections in indians of the southwestern part of the state of Bolivar, Venezuela. American Journal of Tropical Medicine and Hygiene, 29: 373-376.

Lacerda, N.B.; Rachou, R.G. 1956. Filarioses humanas nas sedes municipais do estado do Amazonas e territórios do Acre, Guaporé e Rio Branco. Revista Brasileira de Malariologia e Doença Tropicais, 8: 437-442.

Lawrence, N.D.; Erdtmann, B.; Peet, J.W.; Nunes de Mello, J.A.; Hearl, G.R.; James, V.; Neel, M.D.; Salsano, F.M. 1980. Estudos epidemiológicos entre populações indígenas da Amazônia. II. Prevalência da microfilaremia de $M$. ozzardi: Comparação de dois métodos de diagnóstico. Acta Amazonica, 10(4): 763-769.

Medeiros, J.F.; Py-Daniel, V. 2004. Seasonality, parity and transmission indices of Mansonella ozzardi (Manson) (Nematoda: Onchocercidae) by Cerqueirellum argentiscutum (Shelley \& Luna Dias) (Diptera: Simuliidae) in a lower Solimões River community, Amazonas, Brazil. Acta Amazonica, 34(2): 201-207.

Medeiros J.F.; Py-Daniel, V.; Pessoa F.A.C. 2006. Mansonella ozzardi uma filária pouco estudada no Brasil. Ciência Hoje, 39(231): 6870
Moraes, M.A.P.; Almeida, M.M.R.; Lovelace, K.J.; Chaves, G.M. 1978. Mansonella ozzardi entre índios Ticunas do estado do Amazonas, Brasil. Boletin de la Oficina Sanitaria Panamericana, 85: $16-25$.

Nathan, M.B.; Tikasingh, E.S.; Munroe, P. 1982. Filariasis in amerindians of western Guyana with observations on transmission of Mansonella ozzardi by a Simulium species of the amazonicum group. Tropnemedizin Parasitologie, 33: 219-222.

Oliveira, W.R. 1963. Infestação por filárias em habitantes de vila Pereira, território de Roraima, Brasil. Revista do Instituto de Medicina Tropical de São Paulo, 5: 287-288.

Orihel, T.C.; Asr, R.; Ramachandran, R. 1997. Plaches pour identification des filaries. Organisation Mondiale de la Santé, Geneva. 5pp.

Shelley, A.J.; Shelley, A. 1976. Further evidence for the transmission of Mansonella ozzardi by Simulium amazonicum in Brazil. Annals Tropical Medicina Parasitology, 70: 213-217.

Shelley, A.J.; Luna Dias, A.P.A.; Moraes, M.A.P. 1980. Simulium species of amazonicum group as vectors of Mansonella ozzardi in the Brazilian Amazon. Transection Royal Society of Tropical Medical and Hygiene, 74: 784-788.

Tavares, A.M. 1981. Estudo da infecção por Mansonella ozzardi. Dissertação de Mestrado, Universidade de Brasília, Brasília, DF. $121 \mathrm{pp}$.

Yazarbal, L.; Basáñez, M.G.; Ramírez-Pérez, J.; Ramírez, A.; Botto, C.; Yazarbal, A. 1985. Experimental and natural infection of Simulium sanchezi by Mansonella ozzardi in the middle Orinoco region of Venezuela. Transection Royal Society of Tropical Medical and Hyiene, 79: 29-33.

Recebido em 06/10/2006

Aceito em 18/05/2007 
